\title{
СОВЕТСКИЕ ЖЕНЩИНЫ В СИСТЕМЕ ВСЕВОБУЧА
}

\section{SOVIET WOMEN IN THE SYSTEM OF VSEVOBUCH}

\section{G. Parfenova}

Summary: The relevance of this article lies in a transparent historical analogy of the situation of total devastation in Soviet Russia after the Civil War and the current difficult political, economic, and military situation of the Russian Federation, despite the fact that during the years of perestroika, general military and special education, mass defense work, and military patriotic the education of the population was lost in many aspects. Currently, these tasks are being addressed by DOSAAF and the regional organizations of Unarmia.

Keywords: Vsevobuch, People's Commissariat for Education, Red Army, N.I. Podvoisky, police system.
Парфенова Галина Владимировна

аспирант, ФГБОУ ВО «Воронежский Государственный Аграрный Университет имени императора Петра |»

(2. Воронеж)

g.parfenova2012@yandex.ru

Аннотация: Актуальность данной статьи заключается в прозрачной исторической аналогии обстановки тотальной разрухи в Советской России после Гражданской войны и современного сложного политико-экономического и военного положения Российской Федерации, при том, что в годы перестройки общее военное и специальное образование, оборонно-массовая работа и военно-патриотическое воспитание населения были во многих аспектах утрачены. В настоящее время эти задачи решает ДОСААФ и региональные организации Юнармии.

Ключевые слова: Всевобуч, Наркомпрос, Красная Армия, Н.И. Подвойский, милиционная система.
$\mathrm{O}$ ктябрьская революция сразу же превратила военное обучение рабочих в чрезвычайно важное государственное дело.

В период от октября 1917 г. до издания декрета о всеобщем обязательном обучении трудящихся, организация военного обучения рабочих была построена по упрощенной схеме, опирающейся на реальные возможности на местах. Обычно при казармах, в военных тирах, в манежах, пунктах вербовки добровольцев в Красную армию, открывались пункты обучения. Пункты артиллерийского и кавалерийского обучения открывались при бывших военных училищах или артиллерийских дивизионах. К каждому такому пункту прикомандировывались из воинских частей инструкторы из испытанных в революционной борьбе солдат. В распоряжение инструктора отпускалось оружие и боевые припасы. Обучение производилось в одиночку или группами. В первом случае время обучения зависело от самих обучающихся, во втором, обучение производилось вечером и продолжалось от 7 дней до 1,5 месяцев. После агитации, призывов, особых воззваний, газетных статей и объявлений желающие обучаться приходили на пункт обучения, заявляли о своем желании обучаться, представляли свои документы и приступали к занятиям.

22 апреля 1918 г. декретируется обязательность и всеобщность военного обучения. Декретом о Всевобуче [1] ставилась конечная цель: превратить всех трудящихся в вооруженный народ, проводя последовательную подготовку их к этому соответствующим военным воспитанием и образованием. В качестве ближайшей цели ставилось ввести в военное строительство, новый не- бывалый и неизвестный буржуазным кадровым армиям способ подготовки Красной Армии, открывавший возможность быстро и наиболее экономно развивать вооруженные силы молодого социалистического государства и усиливать возможности по увеличению личного состава армии и, также, возмещать ее убыль [2].

Согласно декрета, все граждане трудовых классов от 18 до 40 лет должны были быть взяты на учет и пройти по специальной программе ускоренный курс обучения, рассчитанный на 96 ч., чтобы быть готовыми по первому призыву правительства встать под ружье и пополнить кадры Красной Армии [3].

Роль Всевобуча в истории создания становления Красной Армии в начальный период велика и значительна, ведь одна из первых и главных неотложных задач Советской власти заключалась в создании боеспособной армии. Эта новая армия должна была быть построена на совершенно иных началах, чем прежняя царская армия, которая оказалась, по факту, абсолютно не способной выдержать суровое испытание длительной борьбы с противниками в период Первой Мировой войны и совершенно разложилась задолго до ее окончания [4]. Прежде всего, советская Красная Армия должна была представлять иную в политическом отношении организацию. И насколько старая армия была оторвана от народа и его быта, насколько она служила орудием империалистической политики [5], настолько новая армия должна быть обеспечена от возможности вовлечения в борьбу против воли пролетариата и должна быть близка к народным массам и органически связана их бытом. Таким образом, основным свойством пролетарской и кре- 
стьянской армии должно явиться большее приближение к производственно-хозяйственному укладу новой жизни Советской России [6].

Поскольку старая армия на долгое время отрывала от хозяйственной жизни страны наиболее ценные в производственном отношении возрастные элементы, благодаря более чем своеобразному подходу к мобилизации и комплектованию царской армии [7], постольку новую армию было необходимо строить на началах более тесного сближения с трудовой жизнью рабочих и крестьян, как можно меньше отрывая их от повседневной жизни [8].

Основным путем решения этой проблемы была военная и трудовая подготовка.

Главными задачами Всевобуча были определены, вопервых, допризывной подготовкой, во-вторых, прохождением начального военного обучения по 96-ти часовой программе, в третьих, кратким дополнительным сбором во всевобуческие школы на 28-ми дневный срок, в четвертых, краткими повторными призывами для усовершенствования в те же школы и на маневры и, в пятых, 1-й, 2-й и 3-й ступеней и практического после них стажа для наиболее сознательных, способных и активных юношей и девушек трудящегося населения.

Допризывная подготовка охватывала детей, юношей и девушек, включая школьные возрасты от 8-ми лет. Предполагалось, что благодаря допризывной подготовке молодежь этих возрастов становится здоровыми, крепкими, ловкими, обладающими сильной волей людьми с характером, направленным в сторону пролетарской общественности. Идеологи допризывной подготовки считали, что это достигается массовыми играми, общими спортивными упражнениями и участием всех допризывников в выполнении хозяйственных задач для общественных надобностей.

Физическая подготовка молодежи позиционировалась как часть общей физической культуры. Вопросам постановки физической культуры в Красной Армии и среди допризывников были посвящены статьи Н.И. Подвойского и других авторов для газет и журналов о задачах всеобщего военного обучения в России.

Корреспондент газеты «Новый путь» от 27 августа 1921 г. писал в статье «Новая область Советского строительства», что в Советской России физическая культура есть социальное явление, ставящее себе задачей массовое преобразование здоровых, трудовых, бытовых навыков... «Во главе этого нового движения России стоит пионер Октябрьской Революции, главный начальник всеобщего военного обучения Н.И. Подвойский». Подвойский Николай Ильич (1880 - 1948) - профессиональный революционер, член Коммунистической партии с 1901. В 1912 - 1914 гг. участвовал в организации газет «Звезда» и «Правда»; в 1917 г. - член Петроградского комитета РСДРП(б). В дни Великой Октябрьской социалистической революции - председатель Военно-революционного комитета в Петрограде. После 1917 г. - член Коллегии наркомата по военным делам, член ЦКК ВКП(б). Выдающийся военный организатор, стоявший у истоков Всевобуча и ОСОАВИАХИМа [9].

Благодаря его неутомимой творческой энергии в дело физического оздоровления пролетариата и развития Красного спорта были вовлечены лучшие научные силы, профессора-академики, специалисты с большой эрудицией по вопросам физической культуры [10].

На Пленуме ЦК РКП по работе среди женщин в своем докладе Н.И. Подвойский подчеркнул, что «участие женщин в военном деле для защиты родины пролетариата неизбежно, поэтому женщина-работница должна владеть винтовкой, револьвером и пулеметом, чтобы уметь защищать свой город, свою деревню, своих детей, себя саму при набегах белогвардейских банд. Привлечение женщин для защиты революции при планомерной подготовке глубоких резервов даст стране не только экономию сил, но и будет иметь огромное значение как политическое, так и воспитательное. С одной стороны, это освободит часть квалифицированных рабочих от военного дела и вернет их на трудовой фронт, а с другой стороны, позволит заменять женской службой встречающиеся еще в армии недобросовестные элементы».

Было особо отмечено, что участие женщин в военном деле, в защите родины и пролетарской революции будет и в семье, и в государстве укором мужчинам, отлынивающим от исполнения долга гражданина.

Кроме того, «тесное сотрудничество женщин и мужчин в области формирования трудчастей возложенного на Всевобуч, усилит работу по борьбе с разрухой и доведет тыл до боевого состояния».

Наряду с политической работой, а Отделы работниц должны были развить широкую работу в области ознакомления женщин работниц с опасностью, грозящей всем завоеваниям трудящихся, женщины и девушки от 16 лет должны были заниматься спортом и гимнастикой, предшествующим военной подготовке. Все женщиныработницы свыше 18 лет должны были широко привлекаться, через отделы работниц по районам, в качестве добровольцев к Всевобучу для ознакомления с административной, военно-хозяйственной, санитарной работой, службой связи и по особо заявленному желанию для обучения винтовке и пулемету. В деревнях было введено обязательное обучение гимнастике и спорту для девушек от 16-18 лет [11]. 
Из тезисов доклада Н.И. Подвойского: «Физическая культура, увлекающая мужскую молодежь, разбила также инертность и предрассудки женской молодежи. Теперь нет новой организации по физической культуре, где рядом с юношей мужчиной не занималась бы девушка, равно как нет организации, где не было бы детей. Девушек в организациях уже теперь от 10 до $15 \%$, детей несколько больше. Девушки-пролетарки и крестьянки вместе с мужской молодежью готовятся также и к преподавательской и инструкторской работе в области физической культуры и допризывной подготовки; в каждой инструкторской школе Всевобуча готовятся к преподаванию вместе с мужчинами также девушки» [12].

Важно подчеркнуть, что одновременно с физическим развитием допризывная подготовка должна была уничтожать неграмотность среди юношества, просвещать его, делать молодых людей политически сознательными участниками устройства Советской Республики и защиты еe.

Была четко определена цель военного обучения образовательная, политическая, военно-теоретическая подготовка до 18 лет ранее физически укрепленного и закаленного юноши в роли воина. Вслед за прохождением программы физического развития и допризывной подготовки, юношам предстояло пройти 96-ти часовую программу военного образования. Эта программа готовила юношей и девушек к умению владеть оружием и к умению действовать в составе звена [13].

В тезисах доклада Всевобуча на российском совещании были перечислены основные принципы и задачи по партийной работе среди женщин и в связи с ликвидацией фронтов, как первоочередная задача выдвигалось усиленное хозяйственное строительство. Это вынуждало приступить к перестройке Красной Армии на началах наиболее благоприятствующих такой экономической деятельности и в вопросе о дальнейшем строительстве советских Военных Сил женщина-работница, конечно, должна была сказать свое веское слово.

Допризывная подготовка была определена основой милиционной системы, которую Всевобуч проводил при содействии органов Наркомпроса и союза Молодежи. Милиционная система предусматривала народное ополчение, выставляемое в случае войны. Она имела в мирное время лишь небольшие кадры военных инструкторов и переменный состав, призываемый для кратко- срочного обучения. Сотни юношей и девушек занимались на площадках и в клубах Всевобуча [14]. Для членов Коммунистического Союза молодежи (КСМ) посещение этих занятий являлось обязательным. Была поставлена задача достигнуть того же и по отношению ко всей остальной массе девушек.

К обязательному военному обучению коммунисток по 9-часовой программе стремились привлекать и беспартийных работниц и крестьянок. Всевобуч осуществлял эту работу под руководством партийных органов при содействии профсоюзов, которые вовлекали в это дело всех рабочих и работниц. Отделы по работе среди женщин должны были прийти на помощь в этом своей пропагандой среди работниц и крестьянок.

Для усовершенствования полученных познаний и подготовки инструкторов Всевобуч открыл для женщин (в размере 20\%) вакансии на всех его окружных курсах спорта и допризывной подготовки. Это мероприятие должно было дать для каждого выпуска до 1,5 тыс. женщин инструкторов.

Планировалось, что следующей задачей должна явиться подготовка женщин к несению хозяйственноадминистративной службы в специальных родах войск. В этих целях Всевобучем организовывались и открывались по всем губернским городам краткосрочные курсы для обучения санитарному делу, хозяйственно-административной службе и связи, что должно было резко поднять общую техническую квалификацию женского населения и помочь выполнению целого ряда очередных хозяйственных задач.

Связь между органами Всевобуча и Отделами работниц была возложена на постоянное представительство Отделов работниц в органах Всевобуча. В целях освещения и популяризации данной деятельности в широких массах, издавались специальные журналы, посвященные строительству милиционной системы «К новой армии», и «Вестник милиционной армии» [15].

Результатом такой небывалой в истории человечества по масштабам и задачам работы явилось создание в СССР поистине гигантского резерва квалифицированных трудовых сил, подготовленных к возможной войне, и именно это обстоятельство стало одним из основных факторов, обеспечивших Советскому Союзу победу в Великой Отечественной войне.

2. РГВА. Ф. 65. ОП. 13. Д.27.Л. 22. 
3. РГВА, там же, Л. 123.

4. Бескровный Л.Г. Армия и флот России в начале XX в. Очерки военно-экономического потенциала. М.: Наука, 1986. - С. 5-6.

5. Ленин В.И. Полн. собр. Соч. Т. 9. С. 130.

6. РГВА.Ф.65. ОП. 13.Д.27.Л.122.

7. Бескровный Л.Г. Армия и флот России в начале XX в. Очерки военно-экономического потенциала. М.: Наука, 1986. - С. 9-17.

8. РГВА.Ф. 65. 0п. 13. Д. 27.Л. 42.

9. Энциклопедический словарь. Т. 2. М.: Большая советская энциклопедия, 1954. - С. 667.

10. РГВА. Ф. 65. ОП.13.Д. 27.Л. 8.

11. РГВА, там же, Л. 159.

12. РГВА, там же, Л. 262.

13. РГВА, там же, Л. 43.

14. Малая советская энциклопедия. Второе издание. Т. 6. М.: ОГИЗ РСФСР, 1937. - С. 903.

15. РГВА. Ф. 65. 0п. 13. Д. 67. Л. 24.

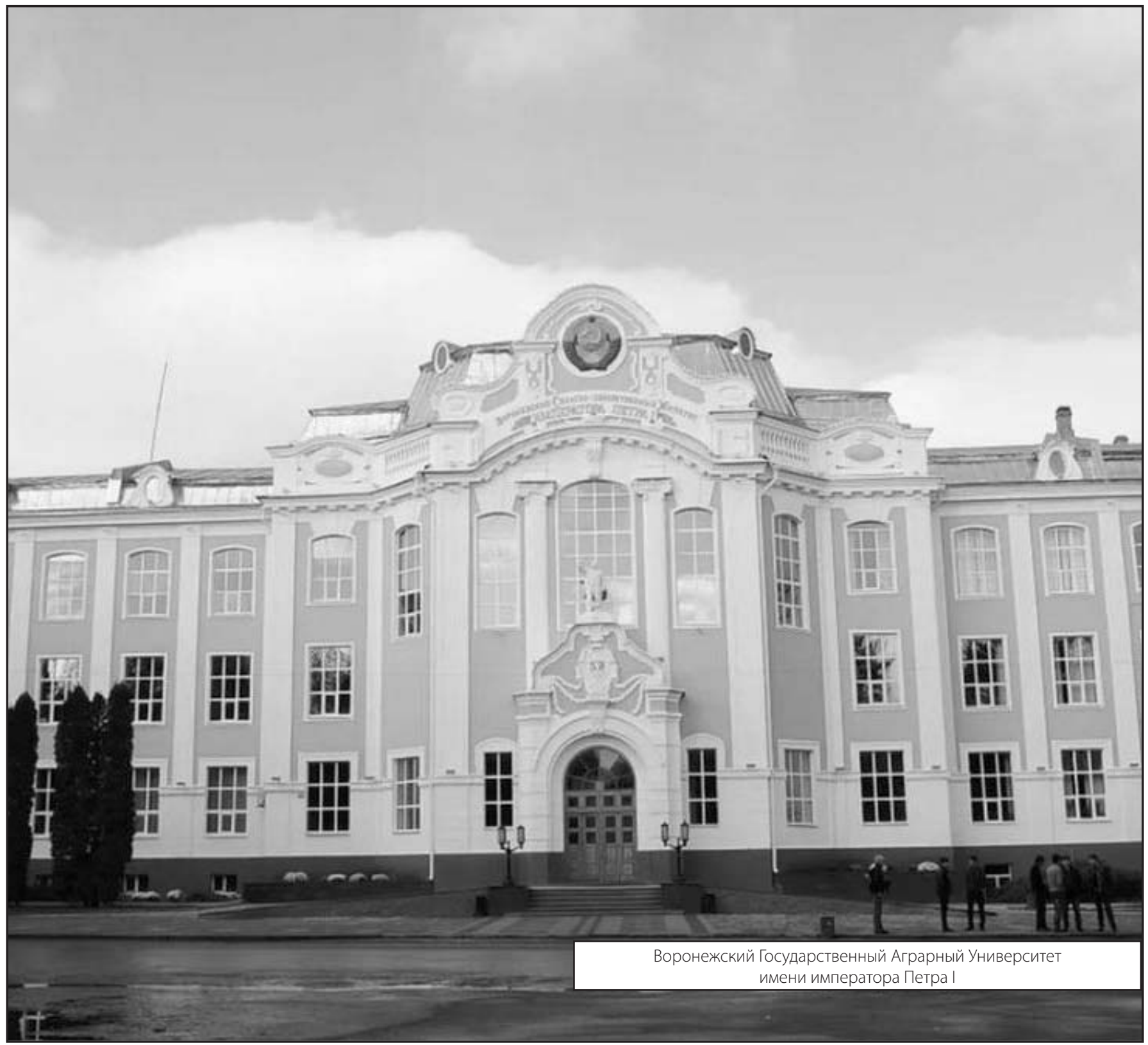

